\title{
Community reporting system: road violation
}

\author{
M. R. Roslan, Suriza Ahmad Zabidi \\ Department of Electrical and Computer Engineering, International Islamic University Malaysia, Malaysia
}

\begin{tabular}{l} 
Article Info \\
\hline Article history: \\
Received Feb 1, 2019 \\
Revised May 28, 2019 \\
Accepted Jun 20, 2019 \\
\hline Keywords: \\
Android \\
Authority \\
Community \\
Reporting system \\
Road violation \\
\hline
\end{tabular}

\begin{abstract}
In the era of internet and wireless, an online community reporting system that is easy to use and hustle free is much needed to allow the user to place a misconduct report to the relevant authority. The available system is inefficient and time-consuming since mostly are using web-based which makes the user unwilling to make a report to the authority. The objective of this project is to design a system using android application that is cost-effective and easy to use. The scope of this project is on the road violation reporting system. The outcome of the system will provide a user with an easy reporting system and also the authority can manage the report easily. The development of the system is expected to enhance the reporting system and betterment for the community as well as the authority as a whole.

Copyright $\odot 2019$ Institute of Advanced Engineering and Science. All rights reserved.
\end{abstract}

Corresponding Author:

Suriza Ahmad Zabidi,

Department of Electrical and Computer Engineering,

International Islamic University Malaysia,

53100 Kuala Lumpur, Malaysia.

Email: suriza@iium.edu.my

\section{INTRODUCTION}

In the era of internet, the online reporting system is an easy and much needed of application due to its robustness, easy and low-cost system. The misconduct and road violation can be reported to the authorities as soon as the incident occurred instead of just posting in the social media. The vulnerable of the internet, however, there will be many misuses of the social network. Thus, it might cause many problems to the authority, and the action maybe takes on the wrong people.

Some people may use the incident to popularize their story to become famous and gain more followers. The social network also has many fake accounts to hide people identity from the authorities-any cases of information security breaches affecting the individual, such as hackers, identity theft, and information devices theft (such as mobile phones and laptops) [1]. In this case, authorities such as the Police Department (PDRM) and the Road Transport Department (JPJ) will have difficulties in tracing the criminals or offenders that have been reported [2]. One of the solutions to encounter this problem is to develop a portable mobile application for community reporting services. This system will require people to enter their valid details before sending their report. Moreover, by having this application, reporting process will become easier and real-time, anywhere and anytime. The authority also can manage the reports easily because they come from the registered user.

There exist a system that implementing the reporting system worldwide. For example, a community in South Windsor, Connecticut [3] developed a mobile application for their residents. It is an iOS mobile application that allows the resident to report from a broken stop sign to a missed junk pickup. The app also allows the community to report a defective streetlight and illegal dumping. This application works by utilizing the GPS capabilities on an iOS device so a resident can send the area of the issue or problem and utilize the basic service request form to describe the issue [4]. 
Another example is crowdsourcing, which is a method that acts as a mindset or progress challenge to the association to realize what their "base of minds"[5]. Crowdsourcing can produce something bigger such as crime information by connecting online with people [6]. A web-based application named "Online Crime Reporting" provides a facility for reporting crimes, show unidentified dead bodies, stolen vehicles, missing people, show most wanted individual details and show snatchers [7]. Their objective is to provide all crime management solutions so that everyone can easily access the system. The people are expected to log a complaint through the website so that the police department can find out the problem easily. Also, people are not coming to the police station every time.

Google's security model was introduced to ensure the security of Android apps [8, 9]. Android requires apps to ask for authorization before the applications can utilize certain framework information and features. The present reporting system also is a manual system [10]. All the record is kept in archived shape and stored in different sorts of registers. As a result, case documents are dumped in piles while some are kept on racks and get dusty quickly, and some of them are seriously damaged. The following table illustrates the summary of a literature review on other researcher's work that related to the community reporting system.

Table 1. Summary table of related work

\begin{tabular}{|c|c|c|c|c|}
\hline Year & Author & Title & Strength & Limitations \\
\hline 2015 & $\begin{array}{l}\text { Carla } \\
\text { Wheeler and } \\
\text { Jim } \\
\text { Baumann[3] }\end{array}$ & $\begin{array}{l}\text { Small Town, Big } \\
\text { Dreams }\end{array}$ & $\begin{array}{l}\text { - Use GPS capabilities to send the area of the } \\
\text { problem. }\end{array}$ & $\begin{array}{l}\text { - Use iOS as the platform for } \\
\text { their mobile app. }\end{array}$ \\
\hline 2016 & $\begin{array}{l}\text { Aunamika .I } \\
\text { and } \\
\text { Tithi .S[4] }\end{array}$ & $\begin{array}{l}\text { Crime Mapping } \\
\text { Through Digital } \\
\text { Data Analysis } \\
\text { From Intermediate } \\
\text { Repository by } \\
\text { Crowd Sourcing }\end{array}$ & $\begin{array}{l}\text { - Created a near real-time service by } \\
\text { crowdsourcing approach. } \\
\text { - Users can collect and share reports, } \\
\text { describe the crime and send message alerts. } \\
\text { - Use Android as the platform for their app. }\end{array}$ & $\begin{array}{l}\text { - They could not get such } \\
\text { dependable, organized data and } \\
\text { information. }\end{array}$ \\
\hline 2017 & $\begin{array}{l}\text { Aswini .G, } \\
\text { Dhivya .N, } \\
\text { Jayanthi .R, } \\
\text { Ambikapathy } \\
\text { R. [13] }\end{array}$ & $\begin{array}{l}\text { Fall Detection and } \\
\text { Reporting Using } \\
\text { Smartphone }\end{array}$ & $\begin{array}{l}\text {-Users seek help by shaking their } \\
\text { smartphones while in a dangerous situation. } \\
\text { - Send GPS location and SOS message to } \\
\text { police or trusted contacts. } \\
\text { - Use Android as the platform for their app. }\end{array}$ & $\begin{array}{l}\text { - Lead to a misunderstanding } \\
\text { between people because the } \\
\text { phone may shake } \\
\text { unintentionally. }\end{array}$ \\
\hline 2017 & $\begin{array}{l}\text { Public } \\
\text { Complaints } \\
\text { Bureau[14] }\end{array}$ & $\begin{array}{l}\text { Public Complaint } \\
\text { Management } \\
\text { System }\end{array}$ & $\begin{array}{l}\text { - Bigger database since it links with the } \\
\text { government's development program. } \\
\text { - Have the authentication system. }\end{array}$ & $\begin{array}{l}\text { - Do not have the application in } \\
\text { android version. }\end{array}$ \\
\hline 2017 & $\begin{array}{l}\text { Public } \\
\text { Malaysian } \\
\text { Electronic } \\
\text { Government } \\
\text { Services } \\
\text { Berhad[15] }\end{array}$ & $\begin{array}{l}\text { Road Transport } \\
\text { Department }\end{array}$ & $\begin{array}{l}\text { - Integrated government services in one } \\
\text { application. }\end{array}$ & $\begin{array}{l}\text { - Not allowing the user to } \\
\text { register complains online and the } \\
\text { facility to send a message to the } \\
\text { authority also not provided.- } \\
\text { Web-based application. }\end{array}$ \\
\hline
\end{tabular}

\section{RESEARCH METHOD}

Figure 1 is the general block diagram that will be used in developing the system. Android Studio platform is used to develop the system and it is fully managed by the admin that have direct access to the database. Admin it the only person that can manage, add and delete the information. The user only can download the app and use the service provided by the app. The app is linked to the real-time database through an internet connection. Figure 2 and Figure 3 shows the module for the user. Figure 1 is for the registration and login module while Figure 2 is for the reporting module for the user.

This system provides the facilities for users to make a complaint; view Frequents Ask Questions (FAQs) and give feedback. First, users need to download, install and register to get access to the system. Next, users will get their account, and they can enter the system as valid users by using their registered name and password. Then, they can send a direct report to the authority that owns this system. Users may report 
with some proof such as plate number, location, and any images too. Google Maps API shall be at Dispose when the transaction handling is done for the location grabbing purposes. To operate this system, it needs to integrate with Firebase features which are Authentication, Real-Time Database, and Storage.

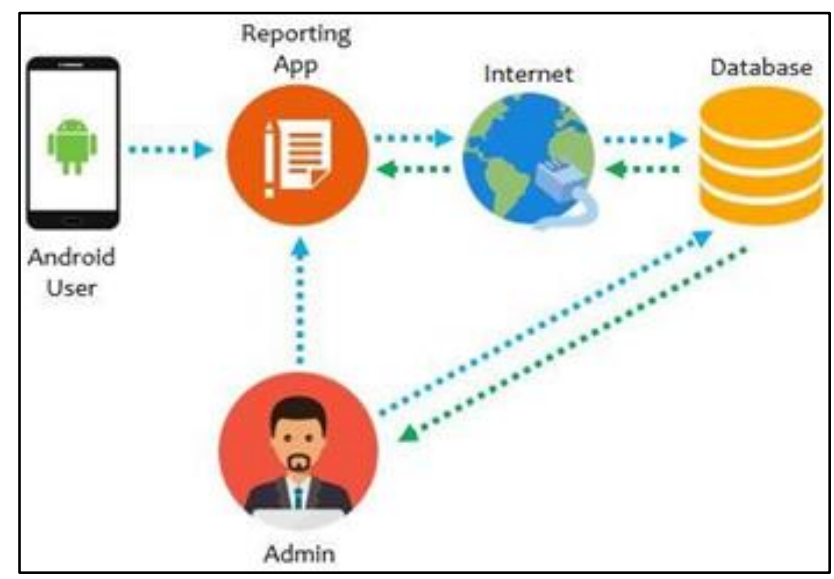

Figure 1. System flow

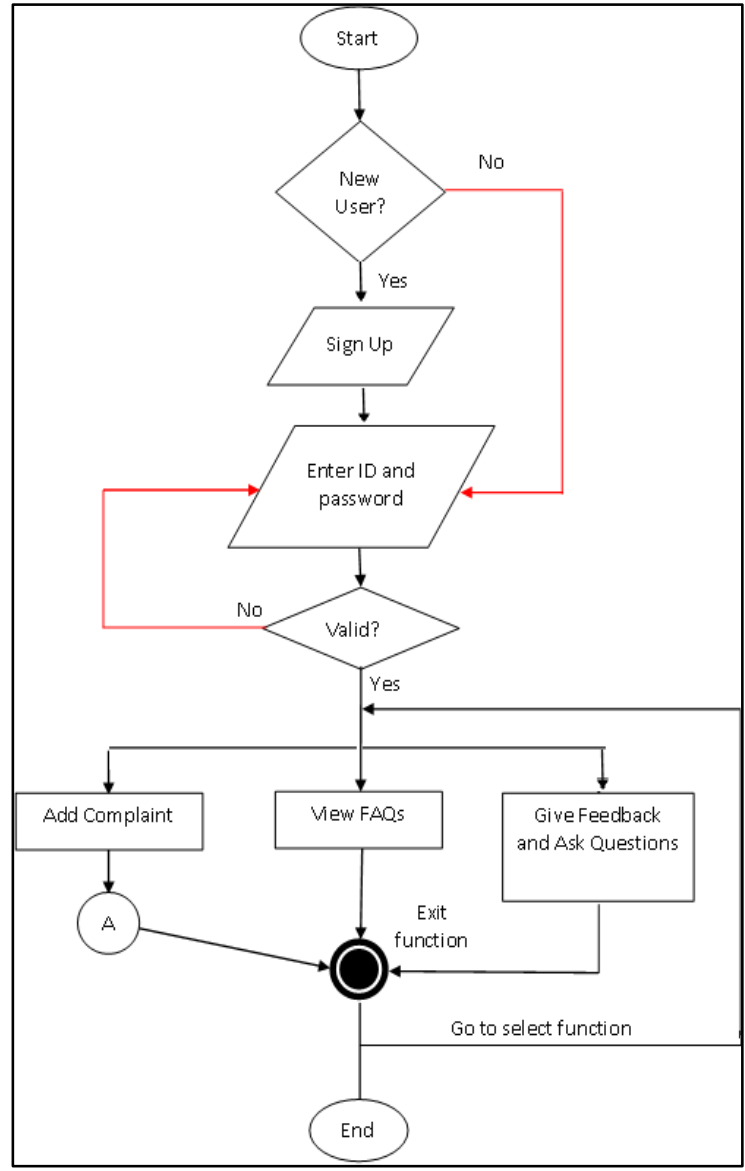

Figure 2. Home activity diagram

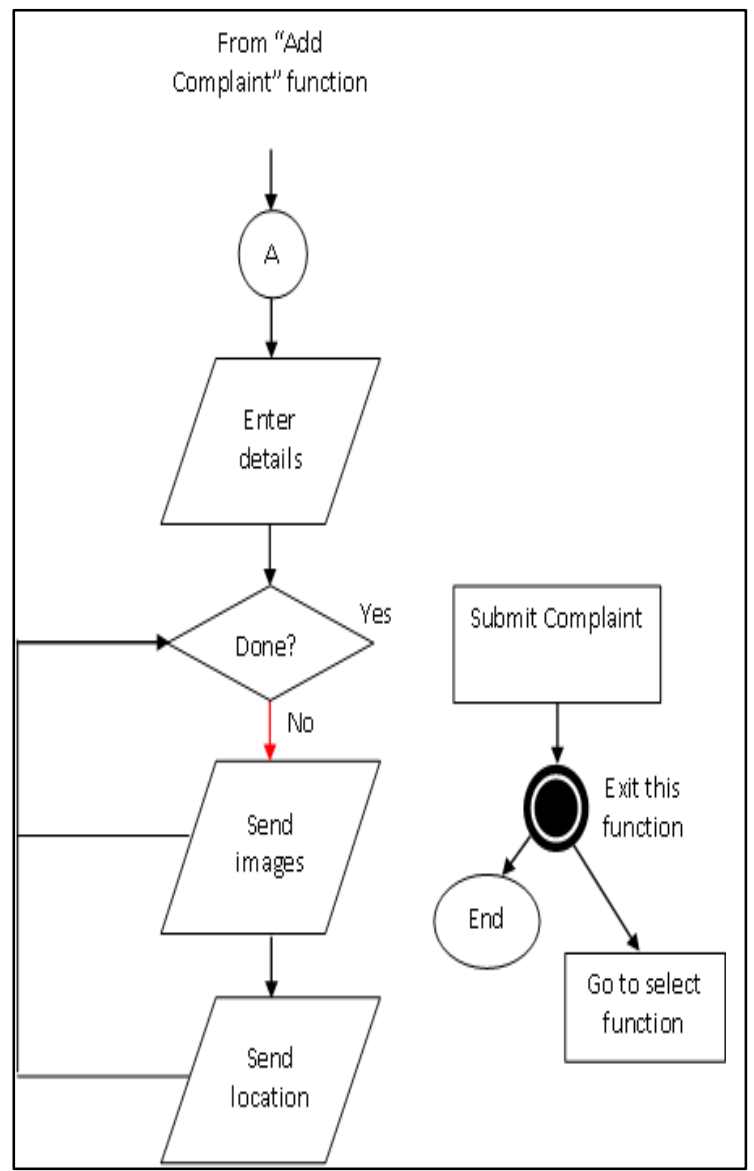

Figure 3. Reporting activity diagram

To submit a report, the user needs to enter the details such as making a report at the authority office. Next, the user can provide their proof such as an image and location. After completing the report, users can submit it directly to the authority. Figure 4 showing the diagram for admin of the system. 


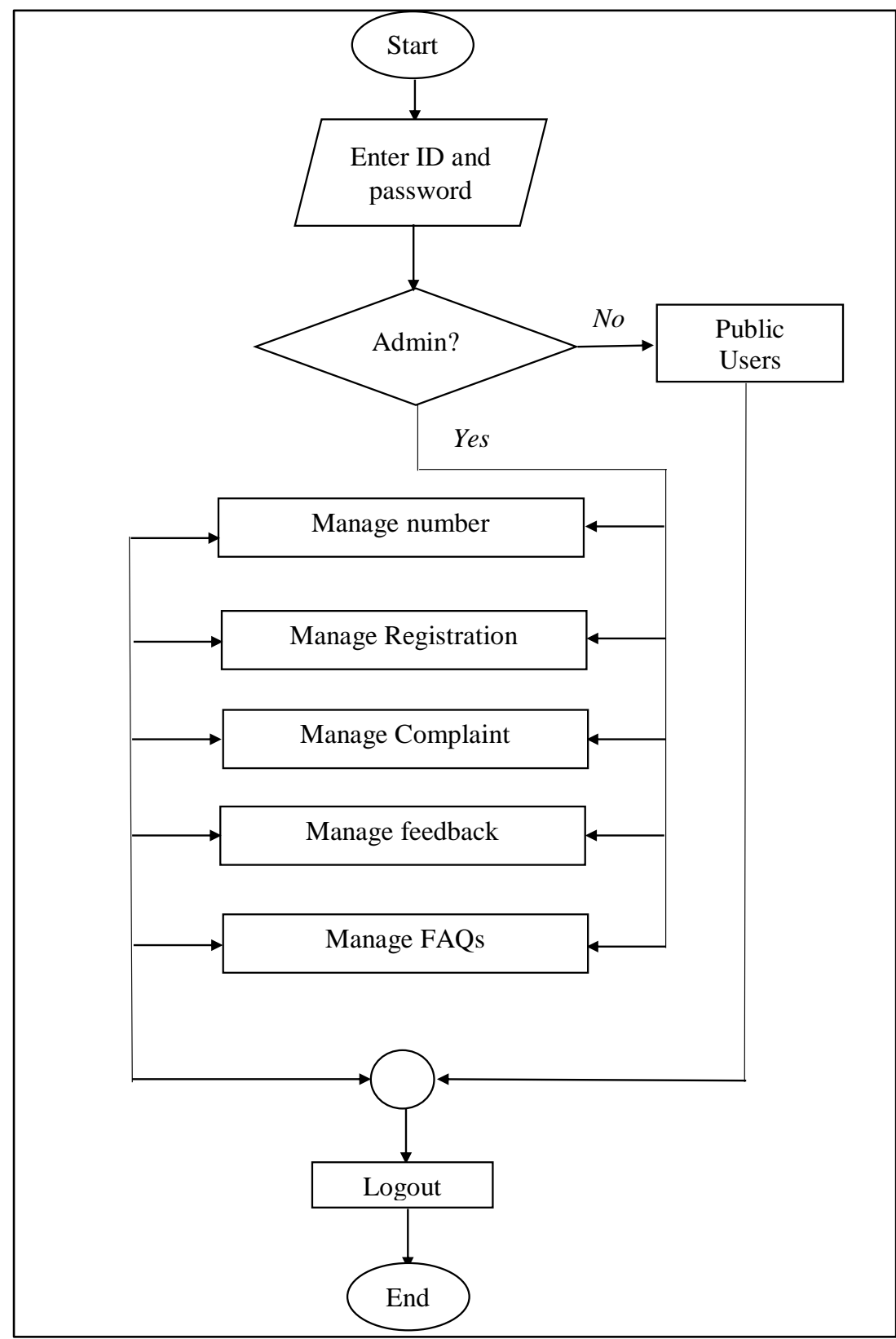

Figure 4. Admin activity diagram

The admin activity has been designing such as a different interface and facilities provided for both admins and users where the admins have special access to it. The features provided in this section are, member management, registration, complaints, FAQs, and feedbacks.

\section{RESULTS AND ANALYSIS}

Admin can monitor, manage the system and its database through Firebase Console. Admin can change the rules of the database, adding and deleting any information, and manage the users and reports. Admin also has the right to change the sign-in method. The system, for now, are using the email/password to enter it, so it needs to make a process called email verification to validate the user email. The valid registered email that will appear in Authentication such as in Figure 5. 


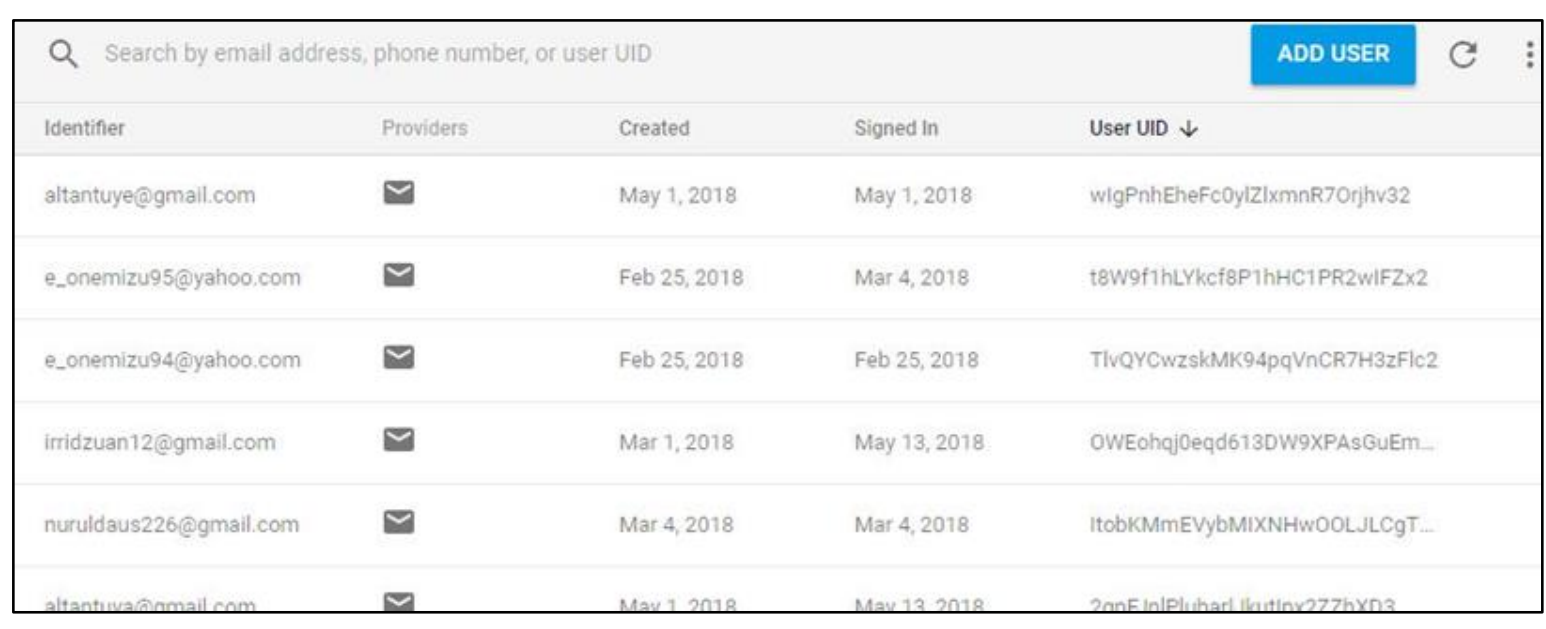

Figure 5. Some of the authenticated users

After registration and authentication by the system for the user, all the data uploaded by the user is stored in Firebase Storage safely. When the user sends a report, the system will automatically update the information in Firebase Database. It will show the details of the reports such as date, identity card (IC) of the user, unique id, report text, time and type of the report as illustrations in Figure 6. Figure 7 shows the identification number of the user arranges the details of the registered user information after the user has filled up the information and the data. Figure 8 shows the login and sign-up screen on the mobile phone of the community reporting system run on an android phone.

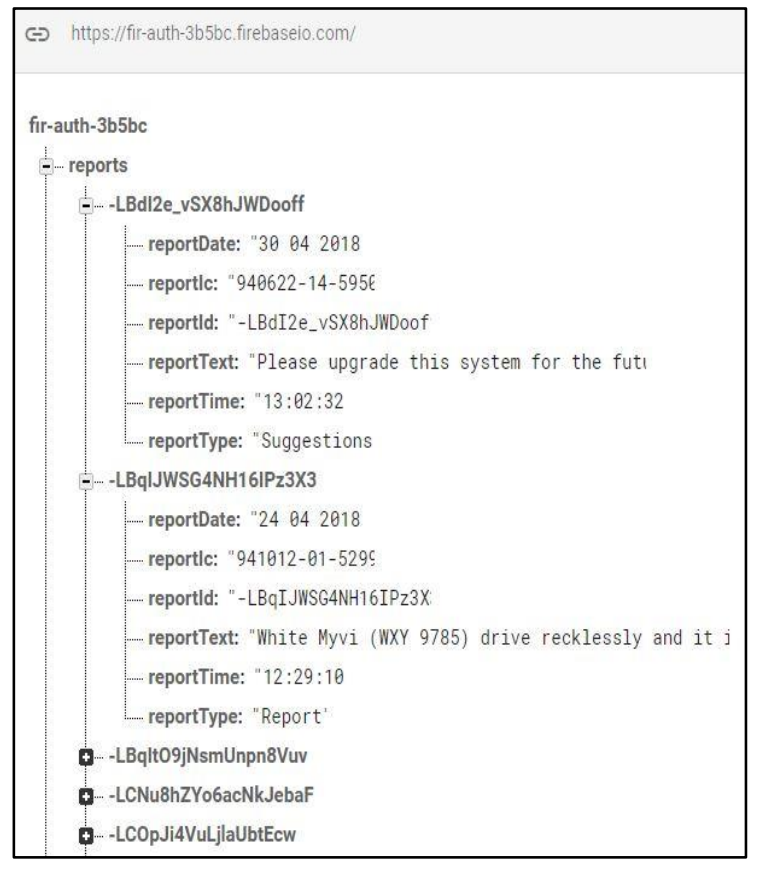

Figure 6. Some of reports received



Figure 7. Some of the registered users

Figure 8 shows the first page of the system. The user needs to sign up before login the system. For those who already sign up, they can log in to the system by fill up the valid email and password. After the user has entered the system successfully, they need to choose their profile picture and username. Next, the user needs to click save to ensure the details has been sent to the system database before they choose to continue. After the user has uploaded both profile picture and username successfully, they need to fill their 
details in the form given. The details collected are a full username, IC number, postal address and phone number of the user. Next, if the user wants to continue to use the services provided, they need to click on 'REPORT' button. Now, User can choose whether to make a report, suggestion or ask a question to the authority and fill the details in the space that has been provided such as in Figure 9.

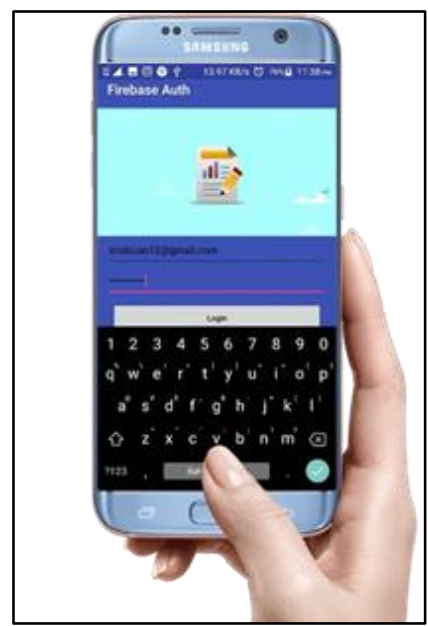

Figure 8. Login and sign up interface

If they have complete the report and want to submit it, they need to click on 'SEND' button. All the input details from the user will be stored in the system database. If they have complete the report and want to submit it, they need to click on 'SEND' button. All the input details from the user will be stored in the system database.

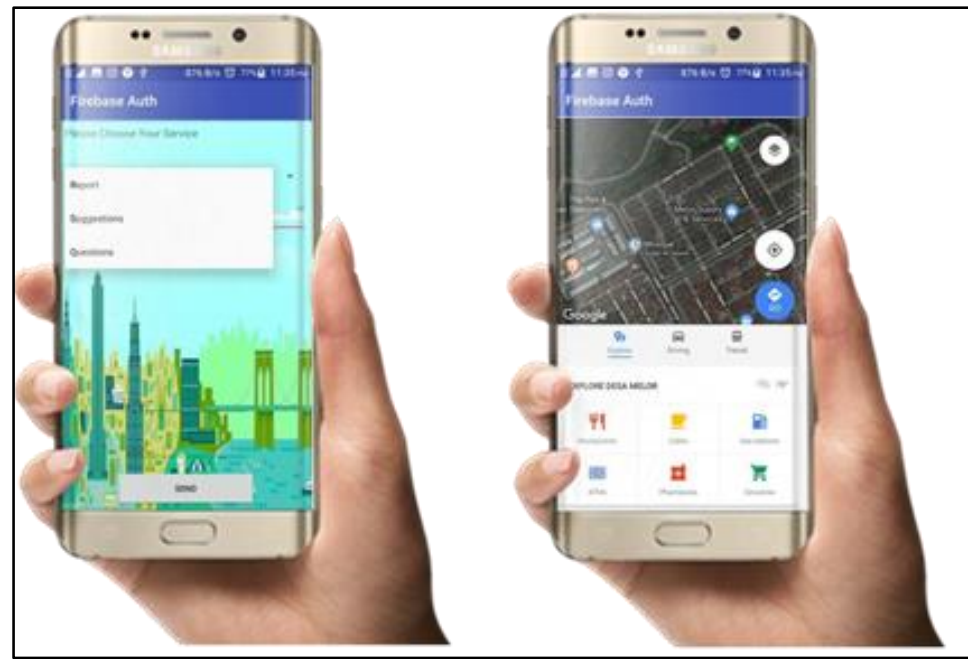

Figure 9. Sending report

\section{CONCLUSION}

The design of this reporting system app will give many benefits to the society especially to the road user and the road authority. Users can save their time by making an online report, and at the same time, the authority can easily manage the complaints and reduce their workload. This system also will help the citizens to make a report easier. Thus, the objectives of this project are achieved, which are to investigate the available and parameters for the system and design an application system that is cost-efficient and user-friendly. There are some limitations to this system. First, the system only suitable for an Android user because this app was developed only for Android. So, citizens that use another operating system cannot use this app. Next, there is no visitor module. All user must need to register to the system before they can use the 
services provided by this system. For the future work, many improvements can be applied to this community reporting system. First, the system can be linked to the Road Transport Department (JPJ) or Police Department (PDRM), so the user can make a direct report about road violation to them without through a third party by using this mobile application. Next, a non-android user such as IOS can use this system by developing it on IOS platform

\section{REFERENCES}

[1] A. Prasetio, P. K. Sari, D. P. Ramadhani, "Electronic Word-of-Mouth (eWOM) Adoption Model for Information Security Awareness: A Case Study in University Students" in Smart Collaboration for Business in Technology and Information Industry, Bandung, 2016.

[2] Saad Suhana and Salman Ali, 2014. "Government policy and the challenge of eradicating human trafficking in Malaysia”, Malaysian Journal of Society and Space. 10 no. 6, pp 66-74, 2014.

[3] Carla Wheeler and Jim Baumann, "Small Town, Big Dreams," Winter 2015, pp48-50, 2015.

[4] Aunamika I., Tithi S. "Crime Mapping through Digital Data Analysis from Intermediate Repository by Crowd Sourcing", BsC Thesis, BRAC University, 2016.

[5] Stevens M, D. Hondt E. "Crowdsourcing of pollution data using smartphones[C]", Workshop on Ubiquitous Crowdsourcing. 2010.

[6] Srivastava, P., Mostafavi, A. "Challenges and Opportunities of Crowdsourcing and Participatory Planning in Developing Infrastructure Systems of Smart Cities". Infrastructures no 3, pp 51. 2018,

[7] Grover, Justin. "Android forensics: Automated data collection and reporting from a mobile device." Digital Investigation Elsevier, 2013 vol. 10, pp S12-S20.

[8] T., Joseph Sahaya Anand et al. "Crimehelp: Crime Scene Description Using Mobile and Web-based Technology for Better Crime Solving”. International Symposium on Research in Innovation and Sustainability 2014 (ISoRIS '14) 15-16 October 2014, Malacca, Malaysia, 2014.

[9] Gunawan, Teddy S., et al. "Design of Automatic Number Plate Recognition on Android Smartphone Platform." Indonesian Journal of Electrical Engineering and Computer Science, vol. 5, no. 1, p. 99, 2017

[10] M. R. Roslan, Suriza A.Z "Design of an application for Community Reporting System," International Conference on Computer and Communication Engineering (ICCCE'18), Kuala Lumpur, pp. 432-436, 2018.

[11] H. Tong. "A Crowdsourcing Based Crime Mapping System," M.S. Thesis, Waseda University, 2014.

[12] H. Alam, "Crime Reporting System". B.Sc. Thesis, University of Agriculture, Peshawar, 2016.

[13] Aswini G., Dhivya N., Jayanthi R., Ambikapathy R., "Fall Detection and Reporting Using Smartphone", International Journal of Advance Research, Ideas and Innovations in Technology, vol 3, no 2, 2017.

[14] Public Complaints Bureau, Sistem Pengurusan Aduan Awam, Road Transport Department Malaysia (JPJ), 2014 (online) http://jpj.spab.gov.my/eApps/ [Accessed: Oct. 10 2017].

[15] Public Malaysian Electronic Government Services Berhad (MyEG), Road Transport Department. (Online). https://app1.myeg.com.my/eservices/ [Accessed: Oct. 3 2017].

[16] S. Kaur, 'Online Reporting System', Department of Computer Science Engineeering, 2016.

\section{BIOGRAPHIES OF AUTHORS}
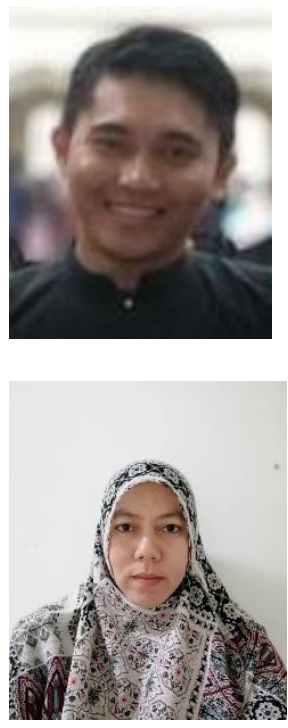

Mohamad Ridzuan Roslan is a candidate for Master in Communication Engineering, at International Islamic University Malaysia. Area of interests is a communication system, coding and computer's related. The material presented in this journal is from his Final Year Project.

Suriza Ahmad Zabidi is a lecturer in Faculty of Engineering, International Islamic University Malaysia. Her research interest is in the area of Wireless Optics, Visible Light Communication, Biometric, and Green Technology. She is a member of Photonics and Radiation Research Group also and IEEE members. 